\title{
Volemic loss in rapid maxilla expansion surgically assisted
}

\author{
Perda volêmica em expansão rápida de maxila assistida cirurgicamente
}

\section{Perdida de sangre en el expansión rápida del maxilar quirúrgicamente asistida \\ Ellen Cristina GAETTI-JARDIM ${ }^{1}$ \\ Leonardo Perez FAVERANI ${ }^{2}$ \\ Roberta OKAMOTO ${ }^{3}$ \\ Elerson GAETTI JARDIM-JÚNIOR ${ }^{4}$ \\ Elio Hitoshi SHINOHARA ${ }^{5}$}

\author{
${ }^{I}$ PhD. Department of Oral and Maxillofacial Surgery, School of Dentistry, Federal University of Mato Grosso do Sul (UFMS), \\ Campo Grande-MS, Brazil \\ ${ }^{2} \mathrm{PhD}$, Division of Oral and Maxillofacial Surgery Department of Surgery and Integrated Clinic, São Paulo State University (Unesp), \\ School of Dentistry, Araçatuba - SP, Brazil \\ ${ }^{3}$ PhD, Division of Oral and Maxillofacial Surgery, Department of Basic Sciences, São Paulo State University (Unesp), \\ School of Dentistry, Araçatuba-SP, Brazil \\ ${ }^{4}$ PhD. Department of Pathology and Clinical Propedeutics, São Paulo State University (Unesp), \\ School of Dentistry, Aracatuba - SP, Brazil \\ ${ }^{5}$ PhD, Division of Oral and Maxillofacial Surgery, Graduate Program in Dentistry, São Paulo State University (Unesp), \\ School of Dentistry, Araçatuba - SP, Brazil
}

\begin{abstract}
Resumo
Cirurgias para correção da deformidade dentofacial são procedimentos que são executados com frequência considerável hoje em dia e, devido à sua complexidade em relação a complicações inerentes à técnica, tais como lesões arteriovenosas ou até mesmo o tempo de cirurgia, possam causar hipovolemia grave. Necessidade de substituição de nível sanguíneo através de infusão de soluções cristalóides, colóides ou mesmo de transfusão de sangue é sempre obrigatória. Desta forma, propõe-se neste estudo para quantificar a perda de sangue, bem como avaliar a necessidade de transfusão de sangue em 19 pacientes que foram submetidos a expansão da maxila. Pacientes e Métodos: Foram avaliadas as pressões arterial média, cirurgia tempo de procedimento, sexo, perda volêmica e classificação ASA. perda média de sangue foi $296,84 \mathrm{~mL}$, com o valor mínimo de $50 \mathrm{~mL}$ e um máximo de $1000 \mathrm{~mL}$. Podemos concluir que a hipovolemia e a requisição de transfusão de sangue, em tais cirurgias, foi de pequeno número. No entanto, os profissionais devem estar alertas quanto ao tempo cirúrgico e ao desenvolvimento de técnica cirúrgica meticulosa.
\end{abstract}

Descritores: Cirurgia; Hipovolemia; Transfusão de Sangue.

\begin{abstract}
Surgeries for dentofacial deformity correction are procedures which are executed with considerable frequency nowadays and, due to their complexity concerning complications inherent to technique, such as arteriovenous lesions or even surgery time, may cause severe hypovolemia. Necessity of replacement of blood level through infusion of crystalloid solutions, colloids or even blood transfusion is always mandatory. This way, it is proposed in this study to quantify blood loss, as well as evaluate necessity of blood transfusion in 19 patients who underwent maxilla expansion. It was evaluated average arterial pressures, surgery procedure time, gender, volemic loss and ASA classification. Average blood loss was $296,84 \mathrm{~mL}$, with minimal value of $50 \mathrm{~mL}$ and maximum $1000 \mathrm{~mL}$. We can conclude that hypovolemia and blood transfusion request in such surgeries was of small number, however, professionals should always be aware of surgical time and development of discerning surgical technique.
\end{abstract}

Descriptors: Surgery; Hypovolemia; Blood Transfusion.

\section{Resumen}

Los procedimientos de cirugía ortognática se llevan a cabo con una corriente considerable y la frecuencia, debido a los informes técnicos inherentes de complicaciones, tales como arteriovenosa o lesiones por tiempo quirúrgico, puede causar hipovolemia severa. La necesidad de sustitución de volumen de sangre a través de las soluciones de infusión de cristaloides, coloides o incluso transfusión de sangre es siempre obligatoria. Por lo tanto, se ha propuesto en este estudio para cuantificar la pérdida de sangre y para evaluar la necesidad de transfusión de sangre en 19 pacientes sometidos a la expansión maxilar. Se evaluaron los valores medios de la presión arterial, el tiempo de la cirugía, el género, la pérdida de volumen y ASA. Se puede concluir que la hipovolemia y la transfusión de solicitud de sangre en estas cirugías eran pequeñas, sin embargo, los profesionales deben estar siempre alerta para el tiempo quirúrgico y el desarrollo de una técnica quirúrgica meticulosa.

Descriptores: Cirurgía; Hipovolemia; Transfusión Sanguínea.

\section{INTRODUCTION}

Human beauty, shown since times of great philosophers in papyri, several centuries ago, is still present in different areas of human knowledge. Thus, individuals are increasingly looking for beauty. In this context, surgeries for dentofacial deformity corrections have been shown as effective, or in the stomatognathic system reestablishment workability, or to improve facial harmony. Evaluations for blood transfusion necessities in surgically assisted maxilla 
rapid expansions (SARME) are not known in the related literature. Although it is a relatively rapid procedure in which many professional use ambulatory environment ${ }^{1}$, sometimes it is necessary to use hypotensive techniques and accurate anatomic knowledge.

There is a broad debate concerning indications of transfusions, since infectious diseases, specially hepatitis B, hepatitis $\mathrm{C}$ and Acquired Immunodeficiency Syndrome (AIDS), are transmitted through blood transfusion. Besides, there is suspicion they cause splanchnic ischemia in blood stock in periods more than 15 days ${ }^{2-4}$.

The loss of $20 \%$ of the blood volume requires between 20 and 60 hours to restore the plasmatic level. This event is followed by mobilization of liquids containing albumin, causing gradual lessening of hematocrit during 2-3 days after blood loss 5 .

Young patient with full health can deal with deficits of 50 to $60 \%$ in its volemic mass. However, patients with advanced cardiovascular disease may suffer myocardium ischemia in losses smaller than $30 \%{ }^{6}$.

Decision of which solution will be used in replenishment of blood losses depends on many factors, including pre-operatory conditions of the patient, the type and length of surgery. Replenishment of red blood cells in large blood losses consists initially in the stimulus of mother cells of bone marrow by erythropoietin, presenting maturation of 2 to 5 days. A patient with a normal erythropoietin mechanism increases red blood cells production between 2 and 3 times, when blood loss is 20 to $30 \%$, but it can fivefold, when hematocrit goes lower than $30 \%$, with iron storage still adequate ${ }^{7}$.

Thus, innumerous medicines are used to induce proper general and hypotensive anesthesia, initially barbiturates represented by pentobarbital and sec barbital and, nowadays benzodiazepines, specially Diazepam (10mg) and Midazolam $(15 \mathrm{mg})$ via oral. These drugs produce excellent sedation, with minimal cardiac and breathing depression ${ }^{8}$.

For induction and maintenance of anesthesia, several classes of medicaments are used, such as volatile inhaling and gaseous agents, which maintain the anesthetic state after administration of an endovenous anesthetic, such as opioid analgesic and neuromuscular betablocker, ensuring hypotensive surgery procedure, what may lead to lesser level of trans-operatory bleeding level ${ }^{9}$.

In some studies of orthognatic surgery, hypovolemia is meaningful, with losses of blood from $1200 \mathrm{~mL}^{10}$ up to $1575 \mathrm{~mL}^{11}$, being essential the volemic replenishment with crystalloids, colloids or even blood transfusion ${ }^{13}$. However, there are still few works, especially in national literature on this field, mainly concerning accurate indications and real necessity of blood transfusion in orthognatic procedures ${ }^{12}$.

Therefore, it is justifiable the accomplishment of this study to alert dental practitioners, above all buccomaxillary facial surgeons about volemic replenishments in SARME, since literature in this matter is scarce. Thus, it was suggested to analyze hypovolemia and blood transfusion necessity according to the patient lost blood values, procedure length, average blood pressure, gender, ASA classification and age of patients as well as effectiveness of the used anesthesia technique.

\section{MATERIAL AND METHOD}

Patients from bucomaxillofacial surgery and traumatology service of São Paulo State University - UNESP who were underwent rapid expansion surgery of the maxilla, from March 2009 through June 2010, were part of this study.
After pre-anesthesia evaluation and identification of surgical risk, only patients without any kind of systemic disorder that could either disable them or cause meaningful alterations in hypovolemia values were chosen.

Patients waited in a lounge room until the beginning of the surgery, than they were taken to the surgery room. So, venoclysis was done, mainly in upper limbs, and the anesthesiologist performed nasotracheal intubation. For that, endovenous anesthesia was used, namely Propofol, and also opioid analgesics (Alfentanil, Sulfentanil or Remifentanil) and inhalants (Nitrous Oxide and Sevoflurano). In case of necessity of diminishing average blood pressure, intravenous beta blockers were injected to maintain arterial hypotension under control.

Blood loss was checked mainly by aspirated blood because the irrigation of surgical area with $0,9 \%$ physiological serum is very used for better visualization of anatomic structures. Other information such as gender, age, surgical procedure length, as well as blood pressure was recorded in files made for this end (Figure 1).

Name:
Gender: ( ) male ( ) female Age:___ years
ASA: ( ) I $\quad$ ( ) II $\quad$ ( ) III :
Surgery: ( ) SARME
Lost blood volume
1) Ringer Lactato:
2) Aspirated volume:
Time of surgical procedure:

Figure 1: Profile of patients (ASA: American Society of Anesthesiologists).

\section{RESULTS}

The research was conducted through analyses of 19 patients, where 10 were male $(52,63 \%)$ and 9 female (47,37\%). According to American Society of Anesthesiologists (ASA), the participants were classified in groups ASA I (73,68\% -14 patients), ASA II (20,05\% - 4 patients), and ASA III $(5,26 \%$ - 1 patient). All individuals underwent rapid maxilla expansion surgically assisted.

Ages of patients averaged 25,42 years-old, between 2nd and 5th decades of life (16 to 44 years old). Values of initial blood pressure showed variation among individuals $(83 \times 50 \mathrm{mmHg}$ to $120 \times 60 \mathrm{mmHg})$. Procedure length was $88,15 \mathrm{~min}$, ranging from 50 to $151 \mathrm{~min}$. Average blood loss was $296,84 \mathrm{~mL}$, with minimal value of $50 \mathrm{~mL}$ and maximum $1000 \mathrm{~mL}$ (Tables 1 to 4 ).

\section{DISCUSSION}

Orthognatic surgery is the treatment of choice for corrections of dentofacial deformities associated with orthodontics. It permits ideal solution of malocclusions and facial alterations, enabling balanced occlusal plane and surrounding structures. This procedure brings aesthetic and functional benefits to patients. However, patients with maxillomandibular deformities desire both to have a beautiful face how to re-establishment of stomatognathic system.

Success of rapid maxilla expansion surgically assisted depends on keeping adequate blood supply to the area in 
question. A technique to verify effects of corticotomy of lateral maxillary walls and osteotomy is the measure of mean lineon blood flow of dental pulp. Results of the study show that ischemia of the pulp may occur through Le Fort I osteotomy. Nevertheless, osteotomy $5 \mathrm{~mm}$ above the apex of the upper teeth and osteotomy of intermaxillar suture, didn't cause any permanent effect in pulp blood flow ${ }^{13}$.

Table 1. Description of the variables evaluated in 19 patients in the sample by comparing the volume loss

\begin{tabular}{lcccccc}
\hline & Age & Gender & $\begin{array}{c}\text { ST } \\
(\mathrm{min})\end{array}$ & $\begin{array}{c}\text { AP } \\
(\mathrm{mmHg})\end{array}$ & $\begin{array}{c}\text { Hypovolemia } \\
(\mathrm{mL})\end{array}$ & ASA \\
\hline Measure & & & & & & \\
\hline Patient 1 & 22 & F & 70 & $110 X 70$ & 100 & I \\
Patient 2 & 27 & F & 85 & $85 X 50$ & 300 & I \\
Patient 3 & 39 & M & 95 & $100 \times 50$ & 300 & I \\
Patient 4 & 37 & F & 151 & $110 X 60$ & 300 & I \\
Patient 5 & 18 & M & 66 & $100 X 62$ & 75 & I \\
Patient 6 & 16 & F & 72 & $90 X 43$ & 100 & I \\
Patient 7 & 28 & F & 50 & $90 X 40$ & 500 & I \\
Patient 8 & 15 & M & 92 & $110 X 65$ & 200 & I \\
Patient 9 & 29 & F & 85 & $103 X 65$ & 50 & I \\
Patient 10 & 22 & F & 64 & $115 X 68$ & 110 & II \\
Patient 11 & 21 & M & 52 & $110 X 65$ & 1000 & I \\
Patient 12 & 21 & M & 67 & $118 X 75$ & 200 & I \\
Patient 13 & 23 & M & 130 & $90 X 50$ & 350 & I \\
Patient 14 & 23 & M & 90 & $102 X 55$ & 200 & III \\
Patient 15 & 16 & M & 103 & $113 X 62$ & 275 & II \\
Patient 16 & 44 & M & 95 & $103 X 60$ & 200 & I \\
Patient 17 & 38 & F & 120 & $120 X 60$ & 980 & II \\
Patient 18 & 17 & M & 103 & $87 X 52$ & 100 & II \\
Patient 19 & 27 & F & 85 & $93 X 48$ & 300 & I \\
\hline & & & & & & \\
\hline
\end{tabular}

Table 2. Description of the characteristics and gender ASA sample

\begin{tabular}{cccc}
\hline Measure & & N & $\%$ \\
\hline \multirow{2}{*}{ Gender } & Male & 10 & 52,63 \\
& Female & 09 & 47,37 \\
\hline \multirow{2}{*}{ ASA } & I & 14 & 73,68 \\
& II & 4 & 20,05 \\
\cline { 2 - 4 } & III & 1 & 5,26 \\
\hline
\end{tabular}

Table 3. Description of the variables evaluated in 19 patient sample

\begin{tabular}{lccc}
\hline Measure & Average & Minimum & Maximum \\
\hline Age & 25,42 & 16,0 & 44,0 \\
AAP & 80,26 & 65,0 & 96,5 \\
ST & 88,15 & 50,0 & 151,0 \\
Hypovolemia & 296,84 & 50,0 & 1000,0 \\
\hline
\end{tabular}

When evaluating blood loss after surgical procedure, approach of individuals without systemic conditions is fundamental, since blood loss is better tolerated by patients under healthy conditions. Myocardium ischemia cases were related in heart disease patients, under volemic loss lesser than $30 \%$ of body blood loss ${ }^{10,14}$. Healthy individuals belonging to groups I and II according to American Society of Anesthesiologists were chosen in this study. The results observed in these groups didn't present prevalent values related to volemia, having just one case of patient ASA III Down syndrome, however, this patient didn't have alterations in hematologic exams that would interfere in this research. The results observed in these groups didn't present prevalent values related to volemia, having just one case of patient ASA III Down syndrome. However, this patient didn't have alterations in hematologic exams that would interfere in this research.

Table 4. Description of the variables evaluated in 19 patients in the sample by comparing the criterion ASA

\begin{tabular}{lccc}
\hline & ASA I & ASA II & ASA III \\
\hline Measure & Average & Average & Average \\
\hline Age & 26,21 & 23,25 & 23,00 \\
AAP & 79,14 & 84,62 & 78,50 \\
ST & 85,37 & 97,50 & 90,00 \\
Hypovolemia & 283,92 & 365,25 & 200,00 \\
\hline
\end{tabular}

There is scarcity at studies related of volemic loss in patients submitted to SARME. Information regularly offered by literature suggests the greater risk of hemorrhage when pterigomaxillary suture disjunction is done, due to the presence of important blood vessels in this region, like pterigoyd plexus, maxillary artery and its ending ramifications, like the descending palatine artery ${ }^{15}$. This work adds, once it shows through an adequate number of patients, the lack of blood transfusion in rapid maxilla expansion surgically assisted. When this surgical procedure is done correctly according all principles of technique by qualified team, accomplishment of surgeries under general hypotensive anesthesia ensure lesser reduction of volemia.

Young adults between 16 and 44 years-old were the patients who were subjected to surgeries in this research, which didn't have meaningful variation in statistic tests used being in accordance with current literature ${ }^{6-8,10,12}$. The explanation is based in hypovolemia, which it is correlated with coagulopathies and other systemic disorders, not having relation with age of the subjects.

Expressive procedures concerning blood loss and volemic replenishment, having reduction of volemic variants, were reported in extensive surgeries like orthognatic surgeries themselves. Many authors associated this event to bimaxillary surgeries ${ }^{16}$ meanwhile others associate it with complexity and long surgical length of these procedures ${ }^{17-20}$.

It is general agreement among consulted authors that the execution of these surgical procedures is under hypotensive general anesthetic in association with endovenous and inhaling medications in trans-surgery. Also, pre-anesthetic drugs, with the intention of keeping reduced cardiac debit and vascular resistance, obtaining surgical rinsing and, consequently, lowering surgery length and hypovolemia are essential ${ }^{8,11,12,18,20,21}$. These concerns support results of this research, once associations of anesthestic medication promoted surgeries with better visualization of operatory field and, due to shorter operatory length as well as improved technical surgery, the volemic loss and necessity of blood transfusion was reduced. 
In situations in which volemic loss is needed, some reports indicated blood transfusion, especially in long duration procedures ${ }^{22}$. This recommendation is also apply for procedures associated to another surgical access for autogenous bone grafting ${ }^{16}$. The volemic replenishment happens by the administration of fluids, crystalloids like the solution of Ringer Lactato, which has similar composition of plasma ${ }^{8,10,12,23}$.

Use of medications to lessen blood loss is not usual in this type of surgery being almost always restricted to cardiac surgeries 12. Some antifibrinolytics are used for reduction of operatory bleeding, such as tranexamic acid21, however it doesn't present indication at first in these procedures. It was observed with the realization of this research that the selection of general hypotensive anesthesia in adequate surgical period makes it unnecessary the blood transfusion or the use of other drugs for obtaining smaller loss of blood.

\section{CONCLUSION}

As a result, it is concluded that, the findings of the present study well demonstrated there were no statistically significant differences on gender, age range, and tested variables. Also, It was possible observe blood transfusion as unnecessary procedure due to professional experience and use of general hypotensive anesthesia commonly indicated for rapid maxilla expansion surgically assisted.

\section{REFERENCES}

1. Bays RA, Greco JM. Surgically assisted rapid palatal expansion: An outpatient technique with long-term stability. J Oral Maxillofac Surg. 1992; 50(2):110-3.

2. Purdy FR, Tweeddale MG, Merrick PM - Association of mortality with age of blood transfused in septic ICU patients. Can J Anaesth. 1997; 44(12):1256-1261.

3. Ness PM, Bourke Dl, Walsh PC. A randomized trial of perioperative hemodilution versus transfusion of preoperatively deposited autologous blood in elective surgery. Transfusion. 1992; 32(3): 226-30.

4. Rottman G, Ness PM. Acute normovolemic hemodilution is a legitimate alternative to allogenic blood transfusion. Transfusion. 1998; 38(5): 477-80.

5. Stoelting RK. Pharmacology and Phisiology in Anesthetic Pratice. $2^{\mathrm{a}}$ ed. Philadelphia: Lippincott Co; 1995.

6. Goodnough LT, Brecher ME, Kanter MH, AuBuchon JP. Transfusion medicine. Second of two part - blood conservation. N Engl J Med. 1999; 340(7): 525-33.

7. De Pree C, Mermillod B, Hoffmeyer P, Beris P. Recombinant human erythropoietin as adjuvant treatment for autologous blood donation in elective surgery with large blood needs: a randomized study. Transfusion. 1997; 37(7): 708-14, 1997;

8. Bell W, Proffit W, White R (Eds): Surgical correction of Dentofacial Deformities, vol 1. Philadelphia, WB Saunders Company, 1980.

9. McKinlay S, Gan TJ - Intraoperative fluid management and choice of fluids - The American Society of Anesthesiologists Inc.2003;127-137.

10. Grando TA, Puricelli E, Bagatini A, Gomes CR, Baião CG, Ponzoni D. Alterações pós-anestésicas do Hematócrito em Cirurgias Ortognáticas. Rev Bras Anestesiol. 2005; 55(1):78-86.

11. Praveen K, Narayanan V, Muthusekhar MR, et al. Hypotensive anaesthesia and blood loss in orthognathic surgery: a clinical study. Br J oral Maxillofac Surg. 2001; 39(2): 138-40.

12. Faverani LP, Pastori CM, Marzola C, Toledo-Filho J L, Capelari MM, Zorzetto DLG, et al. Necessity of sanguineous transfusion in patients submitted to orthognatic surgery with analysis of the hipovolemy. Rev Odontologia ATO. 2010; 10(11): 786-805.

13. Ozturk M, Doruk C, Ozec I, Polat S, Babacan H, Biçaksi AA. Pulpal blood flow: effects of corticotomy and midline osteotomy in surgically assisted rapid palatal expansion. J Craniomaxillofac Surg. 2003; 31(2):97-100.

14. Walt AJ. American college of surgeons committee on trauma: early care of the injured patient. Philadelphia: Ed. Saunders Company; 1982.

15. Mehra P, Cottrell DA, Caiazzo A, Lincoln R. Lifethreatening, delayed epistaxis after surgically assisted rapid palatal expansion: a case report. J Oral Maxillofac Surg. 1999; 57(2):201-4.

16. Samman N, Cheung LK, Tong ACK, et al. Blood loss and transfusion requirements in orthognathic surgery. $\mathrm{J}$ Oral Maxillofac Surg. 1996; 54(1):21-4.

17. Gong SG, Krishnan V, Waack D. Blood transfusions in bimaxillary orthognathic surgery: are they necessary? Int J Adult Orthodon Orthognath Surg. 2002; 17(4):314-7.

18. Dhariwal DK, Gibbons AJ, Kittur MA, Sugar AW. Blood transfusion requirements in bimaxillary osteotomies. Br J Oral Maxillofac Surg. 2004; 42(3):231-5.

19. Kessler P, Hegevald J, Adler W, Zimmermann R, Nkenke E, Neukam FW, Fenner M. Is there a need for autogenous blood donation in Orthognathic Surgery? Plast Reconstr Surg. 2006; 117(2):571-6.

20. Sverzut CE, Trivellato AE, Liporaci-Júnior JL, Sverzut AT, Lopes LMF. Perda de sangue em cirurgia ortognática: apresentação de um caso clínico e revisão de literatura. Rev Int Cir Traumatol Bucomaxilofacial. 2006; 4(14):104-8.

21. Choi WS, Irwin MG, Samman SN. The effect of tranexamic acid on blood loss during orthognathic surgery: a randomized controlled trial. J oral Maxillofac Surg. 2009; 67(1):125-33.

22. Turvey TA. Simultaneous mobilization of the maxilla and mandible: Surgical technique and results. J Oral Maxillofac Surg. 1982; 40(2): 96-9.

23. Nkenke E, Kessler P, Wiltfang J, Neukam FW, Weisbach V. Hemoglobin value reduction and necessity of transfusion in bimaxillary orthognathic surgery. J Oral Maxillofac Surg. 2005; 63(5):623-8.

\section{CONFLICTS OF INTERESTS}

The authors declare no conflicts of interests.

\section{CORRESPONDING AUTHOR}

Ellen Cristina Gaetti Jardim

ellengaetti@gmail.com

Received 15/08/2016 Accepted 05/12/2016 